\title{
25. LEAD ISOTOPIC VARIATIONS IN OLD OCEAN CRUST NEAR THE AZORES1
}

\author{
B. Dupré and C. Göpel, Institut de Physique du Globe \\ and \\ H. Bougault, Institut Francais pour la Recherche et l'Exploitation de la $\mathrm{Mer}^{2}$
}

\begin{abstract}
The aim of DSDP Leg 82 was to decipher the temporal and spatial evolution of Azores Plume. The Pb-isotopic results of this leg are rather complex, and can be summarized as follows:

1. At a given site $(561,558)$, variations of $\mathrm{Pb}$ isotopic compositions are generally accompanied by major changes in trace-element ratios, indicating significant heterogeneity of the source region. There is a correlation between $\mathrm{Pb}$ isotopes and trace elements.

2. In contrast, if all the data (i.e., all studied sites) of Leg 82 are considered together, no correlation can be discerned between $\mathrm{Pb}$ isotopes and trace elements. Site 556, especially, shows abnormal behavior.

3. Leg 82 samples not only cover the entire range of $\mathrm{Pb}$ isotopic composition previously established for the Atlantic Ocean, but extend this field to more radiogenic values.

4. The data are compatible with the hot-spot model proposed by Schilling (1975), if one considers that the Azores Plume itself is isotopically heterogeneous, and that it has been progressively contaminated to various degrees by upper mantle material.
\end{abstract}

\section{INTRODUCTION}

The region between 33 and $38^{\circ} \mathrm{N}$ in Atlantic Ocean was chosen for DSDP Leg 82 because it allows investigation of several geochemical problems in a relatively small area (Fig. 1). Studies on dredged samples from this area, analyzing trace elements (Wood et al., 1979; Bougault and Treuil, 1980; Schilling et al., 1980) and Sr, $\mathrm{He}$, and $\mathrm{Pb}$ isotopes (White et al., 1976; White and Schilling, 1978; O'Nions et al., 1977; Kurz et al., 1982; Sun et al., 1975; Dupré and Allègre, 1980), have already shown the existence of important geochemical variations in this section of the ridge crest.

One aim of our study was to determine if these geochemical variations are related to the "Azores Plume" and to determine the exact geographical and temporal extension of this plume with new trace-element results and $\mathrm{Pb}$ isotopic data obtained on the same samples.

Samples from five sites $(556,558,561,562,564)$ were selected for $\mathrm{Pb}$ isotopic analyses on the basis of traceelement data. Major elements as well as magmatophile elements $(\mathrm{Nb}, \mathrm{Zr}, \mathrm{Ti}, \mathrm{Y}, \mathrm{Zr})$ were analyzed on board with an XRF (X-ray fluorescence) unit (Etoubleau et al., this volume). These latter elements have geochemical characteristics comparable to rare-earth elements (REE) (Bougault et al., this volume; Bougault, 1980; Erlank and Kable, 1976). In an "extended REE diagram," $\mathrm{Nb}$ is located between $\mathrm{La}$ and $\mathrm{Ce}, \mathrm{Zr}$ between $\mathrm{Nd}$ and $\mathrm{Sm}$. Thus, the $\mathrm{Nb} / \mathrm{Zr}$ ratio is comparable to the $\mathrm{La} / \mathrm{Sm}$ ratio and indicates whether the source region is enriched or

\footnotetext{
${ }^{1}$ Bougault, H., Cande, S. C., et al., Init. Repts. DSDP, 82: Washington (U.S. Govt. Printing Office).

2 Addresses: (Dupré and Gopel) Institut de Physique du Globe, Laboratoire de Géochemie and Cosmochimie, Tour 14-24, 4, Place Jussieu, 75230 Paris Cedex 05, France; (Bougault) IFREMER (formerly CNEXO), Centre de Brest, B. P. 337, 29273 Brest Cedex, France.
}

depleted in light rare-earth elements (LREE). An Nb/Zr ratio smaller than the chondritic ratio $(\sim 0.1)$ (Bougault et al., this volume), indicates a depleted source, a larger ratio indicates an enriched mantle.

South of the Hayes Fracture Zone, basalts are found with characteristics of trace-element depletion. To the north of this fracture, samples are more enriched. During Leg 82 , however, two sites (558 and 561) yielded rather complex patterns, in which basalts show depleted, flat, and enriched trace-element characteristics (site chapters, Sites 558 and 561, this volume; Bougault et al., this volume).

Combining trace-element data and isotopic data on the samples is necessary. The variations of magmatophile elements depend on two parameters-the chemical nature of the source region and the partial melting/fractional crystallization histories-but isotope data for the same samples allow us to characterize the nature of the source region and show whether it was homogeneous or heterogeneous.

Before using the $\mathrm{Pb}$ results, it is necessary to test whether alteration processes modified the isotopic composition of this relatively old ocean crust (14-37 Ma). Bulk samples and glass samples were compared, and leaching was performed.

\section{ANALYTICAL TECHNIQUES}

A lot of fresh aphyric glassy basalts were found during Leg 82 . The glasses for analysis were handpicked under a binocular microscope.

The chemical procedure for $\mathrm{Pb}$ separation has been published by Manhes et al. (1978). Before dissolution, samples were leached one hour in warm $6 \mathrm{~N} \mathrm{HCl}$. In three cases, $\mathrm{Pb}$ isotopic composition and $\mathrm{Pb}$ concentration were measured also in the leachates (Table 1).

Some of the samples were analyzed in Paris with a conventional mass spectrometer (Thompson THN 206), and the others were measured in Mainz with a multicollector on the Varian MAT system (Todt et al., 1983). Mass discrimination was controlled by repeated analyses of NBS Pb-standard SRM 981. Small samples (i.e., leachates) were measured with an electron multiplier. 


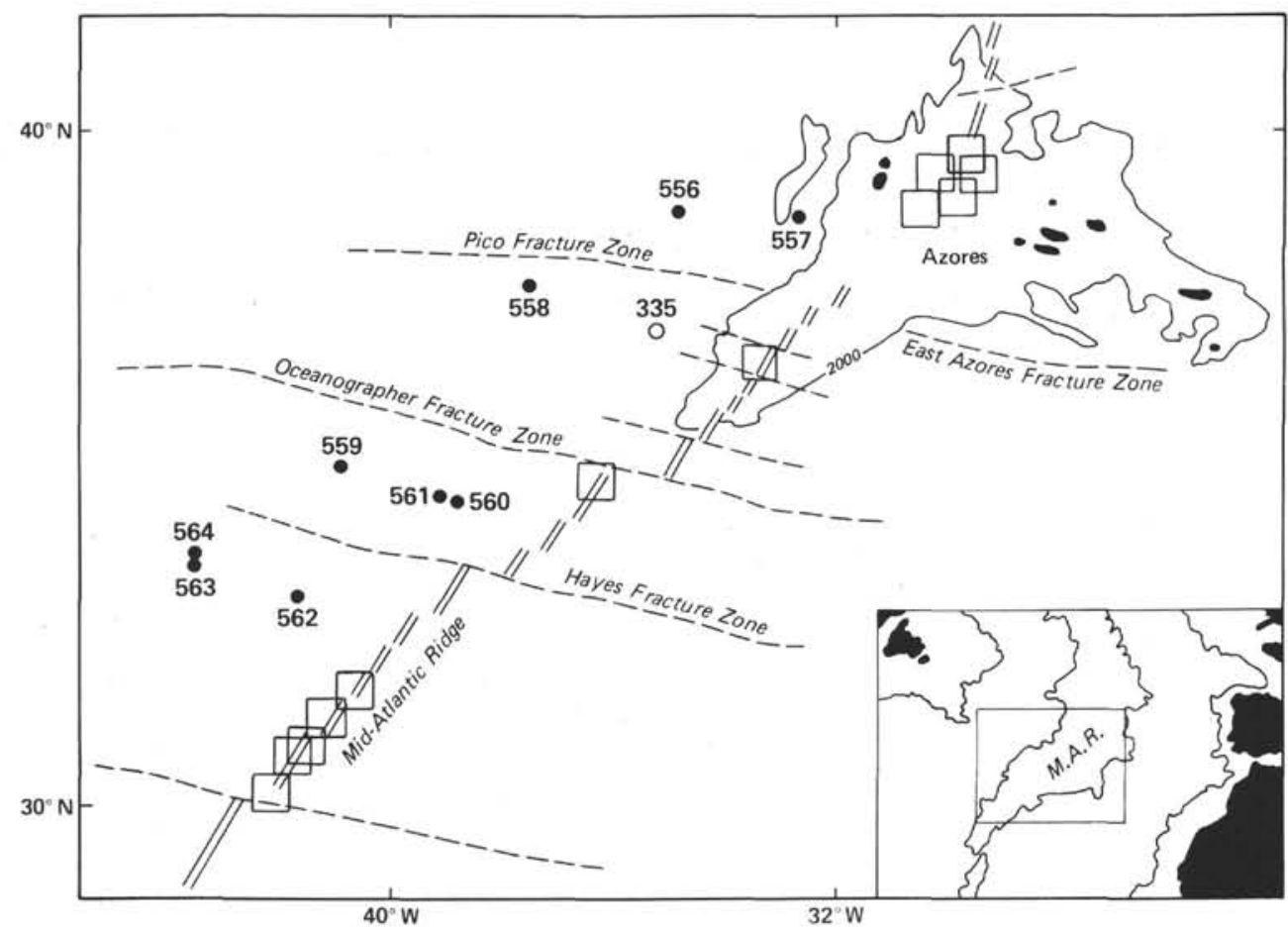

Figure 1. Sketch map of North Atlantic Ocean showing sites (circles) drilled during DSDP Leg 82. Squares represent samples dredged on the ridge crest during former cruises. Site 335 is added for reference only.

\section{RESULTS}

$\mathrm{Pb}$ isotopic compositions of the Leg 82 samples are listed in Table 1 and graphically presented in Figure 2. The observed variations of $\mathrm{Pb}$ isotopic composition in these samples are not only nearly equal to the entire

Table 1. Lead isotopic composition and $\mathrm{Pb}$-concentration analyses of Leg 82 samples.

\begin{tabular}{|c|c|c|c|c|}
\hline $\begin{array}{l}\text { Hole-Core-Section, } \\
\text { interval in } \mathrm{cm} \\
\text { (piece number) }\end{array}$ & ${ }^{206} \mathrm{~Pb} /{ }^{204} \mathrm{~Pb}$ & ${ }^{207} \mathrm{~Pb} /{ }^{204} \mathrm{~Pb}$ & ${ }^{208} \mathrm{~Pb} /{ }^{204} \mathrm{~Pb}$ & $\begin{array}{c}\mathrm{Pb} \\
(\mathrm{ppb})\end{array}$ \\
\hline $558-28-2,75-79 *$ & 19.621 & 15.599 & 39.169 & 264 \\
\hline Leachate & 19.606 & 15.613 & 39.149 & 31 \\
\hline $558-27-3,105-108^{*}$ & 19.676 & 15.619 & 39.405 & 424 \\
\hline $558-39-3,121-124$ & 19.676 & 15.622 & 39.164 & 436 \\
\hline $558-3-33,133-136$ & 20.048 & 15.633 & 39.504 & \\
\hline $558-31-2,39-41$ & 20.253 & 15.634 & 39.625 & \\
\hline $558-33-2,22-25^{*}$ & 20.257 & 15.636 & 39.655 & \\
\hline $558-30-2,78-82$ & 20.249 & 15.632 & 39.616 & \\
\hline $561-2-3,48-62^{*}$ & 18.758 & 15.521 & 38.308 & 267 \\
\hline Leachate & 18.844 & 15.540 & 38.368 & 30 \\
\hline $561-1-1,24-27$ & 19.530 & 15.583 & 39.284 & 535 \\
\hline Leachate & 19.547 & 15.601 & 39.251 & 72 \\
\hline $561-1-1,128-133$ & 18.837 & 15.536 & 38.334 & 134 \\
\hline $561-1-2,19-21$ & 18.827 & 15.530 & 38.356 & 92 \\
\hline $556-6-2,21-23^{*}$ & 19.395 & 15.569 & 38.685 & 439 \\
\hline $556-4-4,71-74^{*}$ & 19.377 & 15.580 & 38.276 & 423 \\
\hline $556-4-2,45-44^{*}$ & 19.562 & 15.583 & 38.721 & 416 \\
\hline $556-4-2,102^{\circ}$ & 19.444 & 15.576 & 38.710 & 424 \\
\hline $556-5-5,72-74^{*}$ & 19.423 & 15.576 & 38.700 & 453 \\
\hline $564-2-2,90-92^{*}$ & 18.399 & 15.498 & 37.833 & 267 \\
\hline $562-1-2,142-145$ & 18.256 & 15.474 & 37.708 & \\
\hline $562-4-41,60-62^{\circ}$ & 18.360 & 15.488 & 37.837 & \\
\hline
\end{tabular}

Note: Asterisks indicate glass samples. range reported for Atlantic Ocean basalts (Church and Tatsumoto, 1975; Cohen and O'Nions 1982; Cohen et al., 1980; Dupré and Allègre, 1980; Dupré et al., 1981; Ito et al., 1982; Sun, 1980; Tatsumoto, 1978), but show even more radiogenic values, with ${ }^{206} \mathrm{~Pb} /{ }^{204} \mathrm{~Pb}$ ratios up to 20.26 . Isotopic heterogeneity is found not only between the different sites of Leg 82 , but also within a given site.

These heterogeneities cannot be due to alteration effects, because the results were obtained on unaltered glasses. Moreover, no difference can be observed between glass and basalt results for the same section of the core (Table 1). The isotopic heterogeneities cannot have been created by in situ decay of $\mathrm{U}$ since the creation of this ocean crust (37 Ma at most): ${ }^{207} \mathrm{~Pb} /{ }^{204} \mathrm{~Pb}$ variations are indeed too large to be explained by in situ $\mathrm{U}$ decay.

\section{Variation of Isotopic Composition at Each Site}

\section{Site 561}

Samples from Site 561 show the widest range of $\mathrm{Pb}$ isotopic composition and trace-element concentrations. These variations can be compared against those previously reported for the FAMOUS area (Dupré et al., 1981), where the ${ }^{206} \mathrm{~Pb} /{ }^{204} \mathrm{~Pb},{ }^{207} \mathrm{~Pb} /{ }^{204} \mathrm{~Pb}$, and ${ }^{208} \mathrm{~Pb} /{ }^{204} \mathrm{~Pb} \mathrm{ra}-$ tios displayed variations of $0.3,0.05$, and 0.25 respectively-much smaller than those for Site 561 alone $(0.8$, 0.06 , and 1). Sample 561-1-1, 24-27 cm, with the most radiogenic $\mathrm{Pb}$ isotopic composition, exhibits also the highest $\mathrm{Nb} / \mathrm{Zr}$ ratio and the highest $\mathrm{Pb}$ concentration (535 ppb). Within analytical error, no difference in $\mathrm{Pb}$ isotopic composition was found between the $\mathrm{HCl}$-leachate of this sample and the final residue; in another glass sample $(561-2-3,48-62 \mathrm{~cm})$, the ${ }^{206} \mathrm{~Pb} /{ }^{204} \mathrm{~Pb}$ ratio showed 


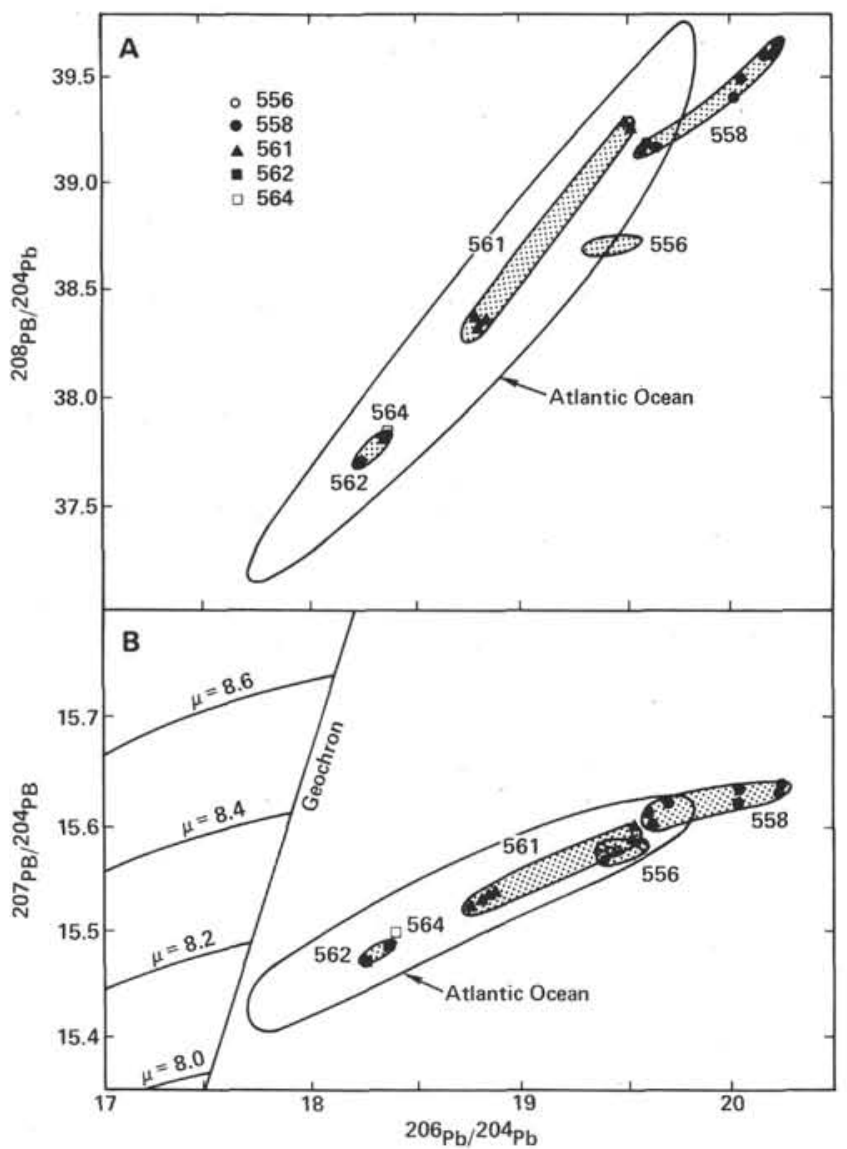

Figure 2. ${ }^{208} \mathrm{~Pb} /{ }^{204} \mathrm{~Pb}$ versus ${ }^{206} \mathrm{~Pb} /{ }^{204} \mathrm{~Pb}(\mathrm{~A})$ and ${ }^{207} \mathrm{~Pb} /{ }^{204} \mathrm{~Pb}$ versus ${ }^{206} \mathrm{~Pb} /{ }^{204} \mathrm{~Pb}(\mathrm{~B})$. Diagrams show the spread in $\mathrm{Pb}$ isotopic compositions of Leg 82 samples in relation to the field of Atlantic Ocean ridge basalts. Variation at a given site is indicated by stippled areas. (Data from Church and Tatsumoto, 1975; Cohen and O'Nions, 1982; Cohen et al., 1980; Dupré and Allègre, 1980; Dupré et al., 1981; Ito et al., 1982; Sun, 1980; Tatsumoto, 1978.)

only a slight difference between the leachate and the residue. Similar observations were published by Cohen and O’Nions (1982).

\section{Site 558 (Hole 558)}

Results for Site 558 are more difficult to interpret. Glass samples and bulk rock show rather evolved $\mathrm{Pb}$ isotopic compositions and extend the domain of the Atlantic Ocean basalts in the ${ }^{206} \mathrm{~Pb} /{ }^{204} \mathrm{~Pb},{ }^{207} \mathrm{~Pb} /{ }^{204} \mathrm{~Pb}$, and ${ }^{208} \mathrm{~Pb} /{ }^{204} \mathrm{~Pb}$ diagrams (Fig. $2 \mathrm{~A}$ and $2 \mathrm{~B}$ ).

Variations of the ${ }^{206} \mathrm{~Pb} /{ }^{204} \mathrm{~Pb},{ }^{207} \mathrm{~Pb} /{ }^{204} \mathrm{~Pb}$, and ${ }^{208} \mathrm{~Pb} /$ ${ }^{204} \mathrm{~Pb}$ ratios at this site are $0.6,0.04$, and 0.5 , respectively-nearly double the variation found in the FAMOUS area.

At Site 558, no perfect correlation is evident between trace elements and isotopes; samples with nearly identical $\mathrm{Nb} / \mathrm{Zr}$ ratios show quite different isotopic compositions.

\section{Site 556}

Samples from Site 556 show the smallest spread in $\mathrm{Pb}$ isotopic compositions. At this site, the variation is comparable to that found in the FAMOUS area. Although the trace-element ratios indicate that these samples are representative of depleted ocean basalts, $\mathrm{Pb}$ isotopic compositions are more evolved, ${ }^{206} \mathrm{~Pb} /{ }^{204} \mathrm{~Pb}$ ratios are higher than 19.0 , and ${ }^{207} \mathrm{~Pb} /{ }^{204} \mathrm{~Pb}$ ratios range up to 15.58 .

\section{Sites 562 and 564}

Three samples were analyzed from sites located south of the Hayes Fracture Zone (Sites 562 and 564). They show low $\mathrm{Nb} / \mathrm{Zr}$ ratios, and yield rather nonradiogenic $\mathrm{Pb}$ isotopic compositions

\section{Summary of Intrasite Isotopic Variation}

The regular variations of $\mathrm{Pb}$ and $\mathrm{Sr}$ isotopes along the ridge crest of the Atlantic Ocean (Dupré et al., 1981; Sun et al., 1975; White et al., 1976, and the results of local studies (Dupré et al., 1981; White and Bryan, 1977; Langmuir et al., 1977), seemed to indicate a relatively good homogeneity of the mantle source at a relatively small scale $(10 \mathrm{~km})$. The Leg 82 results show that this is not always accurate; Leg 82 samples reveal important variations in $\mathrm{Pb}$-isotope composition at a scale of tens of meters at a given site (Sites 558 and 561). A comparable spread of $\mathrm{Pb}$ isotopic compositions was found within a dredge south of the Hayes Fracture Zone by Hamelin et al. (1984).

That these isotopic heterogeneities at Leg 82 sites are generally accompanied by major changes in trace-element ratios can only be interpreted in terms of heterogeneity of the mantle source. Such isotopic variations cannot be created by partial melting or fractional crystallization processes.

\section{Variations between the Leg 82 Holes}

Despite the wide spread of $\mathrm{Pb}$ isotopic compositions at a given site, each site reveals specific features. The most important finding is the geochemical difference between samples drilled north and south of the Hayes Fracture Zone. All samples cored north of this zone exhibit ${ }^{206} \mathrm{~Pb} /{ }^{204} \mathrm{~Pb}$ ratios greater than 18.6 , whereas samples taken farther to the south are less radiogenic. This is compatible with results of trace-element studies on the ridge crest nearby (Bougault and Treuil, 1980; Wood et al., 1979).

Although a correlation exists between trace elements and isotopes at a given site, this correlation no longer holds in a comparison of all sites of Leg 82. This also contrasts with the general trend found for this portion of the Atlantic Ocean (Fig. 3). Samples from Site 556, especially, show abnormal behavior; their trace-element characteristics are typical of depleted basalts, whereas the $\mathrm{Pb}$ isotopes are rather evolved. This apparent discrepancy is important, because the $\mathrm{Pb}$ isotopic composition shows the influence of the "Azores Plume" $34 \mathrm{Ma}$ ago, which is not shown by trace elements.

Our data do not give a unique explanation for this decoupling between $\mathrm{Pb}$ isotopes and trace elements; it may be due to secondary processes (two melting episodes, etc.), which mainly affected the trace elements. It may also be the result of a complex mixing process with the "Azores Plume" in an early stage.

No simple relationship between age and distance to the upwelling Azores can be observed. Along the ridge 


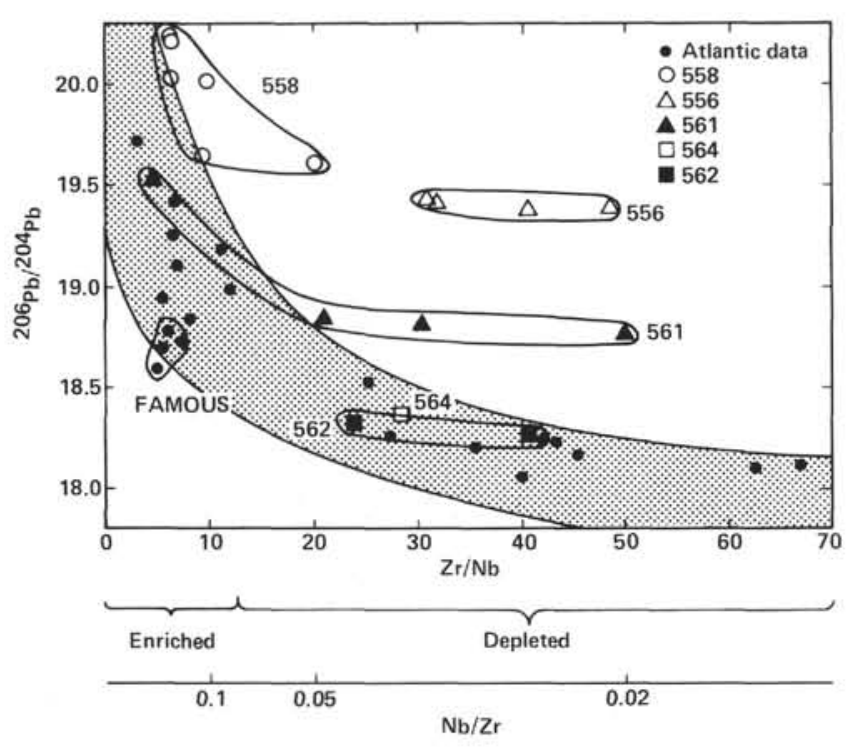

Figure 3. Plot of ${ }^{206} \mathrm{~Pb} /{ }^{204} \mathrm{~Pb}$ versus $\mathrm{Nb} / \mathrm{Zr}$ ratio of $\mathrm{Leg} 82$ samples. The trend of Atlantic Ocean ridge basalts is indicated by shading. Data sources are Bougault et al. (this volume); Bougault, 1980; Dupré et al., 1981; Dupré and Allègre, 1980; Hamelin et al., 1984.

crest between $30^{\circ} \mathrm{N}$ and the Azores, two isotopic "highs" were found (White and Schilling, 1978; White et al., 1976).

The $\mathrm{Pb}$ isotopic data of Leg 82 may be interpreted according to the model proposed by Schilling (1975) (mixing of a plume with upper mantle material), if one considers that the Azores Plume is heterogeneous. The complex characteristics of this plume were shown by Dupré et al. (1982). This may also explain the dispersion of the $\mathrm{Pb}$ isotopic compositions in the ${ }^{208} \mathrm{~Pb} /{ }^{204} \mathrm{~Pb}$ diagram for the samples of Leg 82 (Fig. 2B).

$\mathrm{The} \mathrm{Pb}$ isotopic compositions of the samples from Site 558 are not only more evolved than all other samples from the Atlantic Ocean, but they are even more radiogenic than the alkali basalts from the Azores. This could indicate a mixing process between two sources, one of which (Azores) was less "contaminated" by upper mantle materials $34 \mathrm{Ma}$ ago.

\section{ACKNOWLEDGMENTS}

This study was supported by Action Thematique Programmée. Ocean No. 39-82. We thank S. Hart and J.-G. Schilling for their critical reviews of the manuscript. IPG Contribution Number 711.

\section{REFERENCES}

Bougault, H., 1980. Contribution des éléments de transition à la compréhension de la genèse des basaltes océaniques. Analyse des éléments traces par spectrométrie de fluorescence X [Thèse]. Université Paris VII, Paris.

Bougault, H., and Treuil, M., 1980. Mid-Atlantic Ridge: Zero age geochemical variation between Azores and $22^{\circ} \mathrm{N}$. Nature, 286:209-212.

Church, S. F., and Tatsumoto, M., 1975. Lead isotope relations in oceanic ridge basalts from the Juan de Fuca-Gorda Ridge area. N. E. Pacific Ocean. Contrib. Mineral. Petrol., 53:253-279.

Cohen, R. S., Evensen, N. M., Hamilton, P. J., and O'Nions, R. K., 1980. U-Pb, Sm-Nd and $\mathrm{Rb}-\mathrm{Sr}$ systematics of mid-ocean ridge basalt glasses. Nature, 283:149-153.
Cohen, R. S., O'Nions, R. K., 1982. The lead, neodymium, and strontium isotopic structure of ocean ridge basalts. J. Petrol., 23: 299-324.

Dupré, B., and Allègre, C. J., 1980. Pb-Sr-Nd isotopic correlation and the chemistry of the North Atlantic mantle. Nature, 286: $17-22$.

Dupré, B., Lambret, B., and Allègre, C. J., 1982. Isotopic variations within a single oceanic island: The Terceira case. Nature, 299: 620-622.

Dupré, B., Lambret, B., Rousseau, D., and Allègre, C. J., 1981. Limitations on the scale of mantle heterogeneities under oceanic ridges. Nature, 294:552-554.

Erlank, A. J., and Kable, E. J. D., 1976. The significance of incompatible elements in Mid-Atlantic Ridge basalts from $45^{\circ} \mathrm{N}$, with particular reference to $\mathrm{Zr} / \mathrm{Nb}$. Contrib. Mineral. Petrol., 54:281-291.

Hamelin, B., Dupré, B., and Allègre, C. J., 1984. Lead-strontium isotopic variations along the East Pacific Rise and the Mid-Atlantic Ridge. A comparative study. Earth Planet. Sci. Lett., 67: 340-350.

Ito, E., Göpel, C., White, W. M., Jochum, K. P., Seufert, H., Voshage, H., and Hofmann, A., 1982. Inferences on the composition and evolution of the source of MORB. Fifth Conf. Geochronol., Cosmochronol. Isotope Geol. (Nikko), pp. 166-167.

Kurz, M. D., Jenkins, W. J., Schilling, J. G., and Hart, S. R., 1982. Helium isotopic variations in the mantle beneath the central North Atlantic Ocean. Earth Planet. Sci. Lett., 58:1-14.

Langmuir, C. H., Bender, J. F., Bence, A. E., and Hanson, G. M., 1977. Petrogenesis of basalts from the FAMOUS area: Mid-Atlantic Ridge. Earth Planet. Sci. Lett., 36:133-156.

Manhes, G., Minster, J. F., and Allègre, C. J., 1978. Comparative $\mathrm{U}-\mathrm{Th}-\mathrm{Pb}$ and $\mathrm{Rb}-\mathrm{Sr}$ study of the Saint Séverin amphoterite: Consequence for early solar system chronology. Earth Planet. Sci. Lett., 36:133-156.

O'Nions, R. K., Hamilton, P., and Evensen, N., 1977. Variations in ${ }^{143} \mathrm{Nd} /{ }^{144} \mathrm{Nd}$ and ${ }^{87} \mathrm{Sr} /{ }^{86} \mathrm{Sr}$ ratios in oceanic basalts. Earth Planet. Sci. Lett., 34:13-22.

Schilling, J. G., 1975. Azores mantle blob: rare earth evidence. Earth Planet. Sci. Lett., 25:103-115.

Schilling, J. G., Bergeron, M. B., and Evans, R., 1980. Halogens in the mantle beneath the North Atlantic. Phil. Trans. R. Soc. London, Ser.A, 297:11.

Sun, S. S., 1980. Lead isotopic study of young volcanic rocks from mid-ocean ridges, ocean islands and island arcs. Phil. Trans. $R$. Soc. London, Ser. A, 297:409-445.

Sun, S. S., Tatsumoto, M., and Schilling J. G., 1975. Mantle plume mixing along the Reykjanes axis: lead isotopic evidence. Science, 190:143-147.

Tatsumoto, M., 1978. Isotopic composition of lead in oceanic basalt and its implication to mantle evolution. Earth Planet. Sci. Lett., 38:63-87.

Todt, W., Dupré, B., and Hofmann, A. W., 1983. Pb isotope measurements using a multicollector: application to standards and basalts. E.U.G. 2nd, Terra Cognita, 3:140.

White, W. M., and Bryan, W. B., 1977. Sr-isotope, K, Rb, Cs, Sr, Ba and rare-earth geochemistry of basalts from the FAMOUS area. Geol. Soc. Am. Bull., 88:571-576.

White, W. M., and Schilling, J. G., 1978. The nature and origin of geochemical variations in Mid-Atlantic Ridge basalts from the central North Atlantic. Geochim. Cosmochim. Acta, 42:1501-1516.

White, W. M., Schilling, J. G., and Hart, S. R., 1976. Evidence for the Azores Mantle Plume from strontium isotope geochemistry of the central North Atlantic. Nature, 263:659-663.

Wood, D. A., Tarney, J., Varet, J., Saunders, A. W., Bougault, H., Joron, J. L., Treuil, M., and Cann, J. R., Geochemistry of basalts drilled in the North Atlantic by IPOD Leg 49: implications for mantle heterogeneity. Earth Planet. Sci. Lett., 42:77-97.

Date of Initial Receipt: 17 August 1983 Date of Acceptance: 28 November 1983 